MARIUSZ JAN RADŁO

Szkoła Główna Handlowa, Warszawa, Polska

Warsaw School of Economics, Poland

PaUlina SPAŁEK

Szkoła Główna Handlowa, Warszawa, Polska

Warsaw School of Economics, Poland

\title{
Deklarowana i rzeczywista polityka przemysłowa Polski w świetle danych o pomocy publicznej w latach 2007-2014
}

\section{Declared and Actual Polish Industrial Policy in the Years 2007-2014 in the Context of State Aid Data}

Streszczenie: Celem niniejszego opracowania jest pogłębienie dyskusji o kierunkach polskiej polityki przemysłowej przez porównanie jej deklarowanych i rzeczywistych kierunków w latach 2007-2014. Autorzy opracowania zbadali w szczególności: skalę i strukturę wydatków na wsparcie branż przemysłowych w Polsce, a także dokonali analizy porównawczej kierunków zmian strukturalnych i deklarowanych celów polskiej polityki przemysłowej. W badaniach wskazano, że deklarowane kierunki polityki przemysłowej obejmowały m.in. podniesie poziomu technologicznego polskiej gospodarki, dopasowanie polskiego przemysłu do zmian strukturalnych w światowej gospodarce i podniesienie jego konkurencyjności. Przeprowadzone badania pozwoliły na wykazanie, że rzeczywista polityka przemysłowa, badana z perspektywy branżowych kierunków pomocy publicznej, nie odpowiadała w pełni deklarowanym celom polskiej polityki przemysłowej. Pomoc publiczna nie była kierowana do podmiotów produkujących dobra wysokiej czy chociażby średnio wysokiej techniki, a do przedsiębiorstw działających w przemysłach średnio niskiej techniki oraz podmiotów świadczących usługi rynkowe, tj. usługi detektywistyczne i ochroniarskie, transportu lotniczego oraz magazynowania i wspomagania transportu.

\begin{abstract}
The aim of this study is to broaden the discussion on the directions of Polish industrial policy in the years 2007-2014. Authors of the study examined in particular the scale and structure of expenditure on supporting the development of industry sectors in Poland, and conducted a comparative analysis of the directions of structural changes and the declared objectives of Polish industrial policy. The studies indicated that the declared directions of Polish industrial policy included, among others, the increase of technological level of the Polish economy and its competitiveness, the adjustment of Polish industry to structural changes in the world economy. The research has shown that the actual industrial policy did not fully correspond with the declared aims of Polish industrial policy. The state aid was not channeled to entities producing goods of high or even medium-high technology. Companies operating in the sector of medium-low technology and service providers, namely detective and security services, air transport services, storage and transport support services were the main recipients of this aid.
\end{abstract}

Słowa kluczowe: innowacyjność; polityka przemysłowa; Polska; rozwój; wysoka technika Keywords: development; high technology; industrial policy; innovation; Poland

Otrzymano: 18 grudnia 2016

Received: 18 December 2016

Zaakceptowano: 10 lutego 2017

Accepted: 10 Februrary 2017 


\section{Sugerowana cytacja / Suggested citation:}

Radło, M.J., Spałek, P. (2017). Deklarowana i rzeczywista polityka przemysłowa Polski w świetle danych o pomocy publicznej w latach 2007-2014. Prace Komisji Geografii Przemysłu Polskiego Towarzystwa Geograficznego, 31(1), 7-23.

\section{WSTĘP}

Polityka przemysłowa stanowi jeden z kluczowych obszarów polityki gospodarczej. Jest to jednocześnie polityka, do której podejście istotnie ewoluowało w ostatnich latach zarówno w Polsce, jak i w Unii Europejskiej oraz na świecie. Problemem badawczym, którym zajęto się w niniejszym artykule, są występujące często różnice pomiędzy deklarowaną a realizowaną polityką przemysłową. W tej perspektywie autorzy artykułu podjęli próbę zbadania polskiej polityki przemysłowej w latach 2007-2014 i porównania jej deklarowanych celów z rzeczywistymi kierunkami tej polityki rekonstruowanymi na podstawie struktury pomocy publicznej udzielanej przedsiębiorstwom w Polsce. Autorzy zbadali w szczególności skalę i strukturę wydatków na wsparcie branż przemysłowych w Polsce, dokonali też analizy porównawczej kierunków zmian strukturalnych i deklarowanych celów polskiej polityki przemysłowej. Dodatkowo zbadali, w jakim stopniu udzielone wsparcie dotyczyło przemysłu wysokiej techniki. Artykuł zwraca uwagę na różnice między deklarowaną a rzeczywistą polityką przemysłową w Polsce prowadzoną w latach 2007-2014. Jest to szczególnie istotny problem w kontekście zmiany deklarowanych kierunków polityki przemysłowej zmierzającej w stronę reindustrializacji i selektywnego wspierania branż. Utrzymywanie się ewentualnych rozbieżności pomiędzy deklarowaną a rzeczywistą polityką może stanowić istotny problem w osiąganiu celów polityki gospodarczej, gdyż mogą mieć one charakter permanentny i wynikać z nierozwiązanych problemów strukturalnych gospodarki, siły grup nacisku powiązanych z niektórymi branżami oraz innych czynników.

\section{EWOLUCJA PODEJŚCIA DO POLITYKI PRZEMYSŁOWEJ I JEJ ŹRÓDŁA}

Polityka przemysłowa Polski w ostatnich trzech dekadach przeszła głęboką ewolucję. U zarania transformacji ekonomicznej w Polsce po 1989 roku częste było negowanie potrzeby istnienia tejże polityki - zgodnie z hasłem G. Beckera (1985) o tym, że najlepszą polityką przemysłową jest jej brak. Takie podejście na początku lat dziewięćdziesiątych głosił w Polsce m.in. T. Syryjczyk, minister przemysłu w rządzie T. Mazowieckiego. W podejściu takim - jak wskazywał M. Gorynia (1996) - zakłada się, że obszar zainteresowań polityki gospodarczej jest ograniczony do regulacji procesów pieniężnych i fiskalnych, a jej celem jest doprowadzenie do ogólnej równowagi gospodarczej, która ma prowadzić do równowagi na rynkach cząstkowych. Procesom transformacji gospodarczej towarzyszyły jednak silne zaburzenia na rynkach cząstkowych, całkowita rezygnacja z realizacji polityki przemysłowej w Polsce okazała się więc niemożliwa. Makroekonomiczny program dostosowawczy był więc uzupełniany o polityki dostosowawcze, ukierunkowane na tworzenie instytucjonalnych podstaw przejścia od gospodarki centralnie planowanej do gospodarki rynkowej. Wśród głównych kierunków takiej polityki - jak wskazywał M. Gorynia (1996) - znalazły się polityki wspierania rozwoju (inwestycji, innowacji, edukacji itp.), polityka konkurencji (demonopolizacja, deregulacja, wspieranie konkurencji itp.), polityka prywatyzacji oraz polityka wspierania samorządności gospodarczej. Taka polityka przemysłowa miała charakter horyzontalny i była w praktyce realizowana przez 
całe lata dziewięćdziesiąte i po 2000 roku. Polityka taka dominowała również w okresie po wejściu Polski do Unii Europejskiej w 2004 roku, z tym, że została ona uzupełniona przez szerokie interwencje publiczne - $\mathrm{w}$ zdecydowanym stopniu horyzontalne - realizowane przy wsparciu funduszy UE (Ślusarczyk, 2009).

Renesans selektywnej polityki przemysłowej przyszedł po kryzysie w światowej gospodarce lat 2008-2009. Jak wskazuje R.H. Wade (2015), wspomniany kryzys wywołał szeroką dyskusję na temat efektywności polityki rozwojowej opartej na konsensie waszyngtońskim. Zaznaczył on jednocześnie, że $\mathrm{w}$ wielu krajach z różnych powodów wzrosło zainteresowanie polityką przemysłową. Zaczęto też wskazywać, że praktycznie wszystkie kraje wysoko rozwinięte - w tym m.in. USA, Wielka Brytania, Niemcy, Francja, a także kraje azjatyckie, tj. Korea Południowa, Singapur czy Tajwan - osiągnęły swój sukces gospodarczy dzięki aktywnej polityce przemysłowej (Harrison, Rodriguez-Clare, 2010; Spałek, 2015). Z kolei H.-J. Chang (2007) zarzucił krajom wysoko rozwiniętym, że narzucają krajom doganiającym politykę wolnego handlu, podczas gdy same dochodziły do bogactwa w oparciu o ochronę i wsparcie rodzimych przemysłów raczkujących (m.in. USA, Niemcy, Anglia). Renesansowi selektywnej polityki przemysłowej towarzyszy również rosnące dążenie do reindustrializacji gospodarek krajów rozwiniętych. Trendy te - jak wskazują M. Ulbrych (2016) czy A.A. Ambroziak (2015), są szczególnie widoczne w krajach Unii Europejskiej. Dążenie do reindustrializacji jest również konsekwencją wzrostu znaczenia międzynarodowej fragmentacji produkcji i rozwoju globalnych łańcuchów produkcyjnych, które skutkują przesuwaniem wielu procesów produkcyjnych z krajów wysoko rozwiniętych do krajów rozwijających się i niedawno uprzemysłowionych (Radło, 2016). Ich nasilanie się powoduje wzrost obaw krajów rozwiniętych o utrzymanie wiodącej roli w światowej gospodarce, opartej na innowacyjności i nowoczesnych technologiach rozwijanych głównie w branżach przemysłowych.

Dodatkowo - jak wskazała B. Ślusarczyk (2015) - doświadczenia ostatniego kryzysu finansowego pokazały, że rozwój gospodarki wyłącznie w oparciu o branże usługowe oraz finansowe, przy redukcji roli przemysłu, nie jest korzystny dla jej długofalowego wzrostu. Żadna gospodarka nie jest bowiem w stanie przejść z poziomu niskiego dochodu do poziomu wyższego bez dokonania uprzemysłowienia (Stiglitz, Lin, Monga, 2013). Utrzymanie przewagi konkurencyjnej na wysokim poziomie rozwoju nie jest natomiast możliwe bez ciągłych innowacji - te zaś powstają głównie w przemyśle, który pośrednio przyczynia się do rozwoju nowoczesnych branż usługowych (Gawlikowska-Hueckel, 2014; Radło, 2016). Coraz częściej zaczęto też wskazywać, że odejście od stosowania selektywnej polityki przemysłowej, ochrony branż raczkujących w krajach rozwijających się i liberalizacja handlu spowodowały spowolnienie wzrostu gospodarczego tych krajów (Rynarzewski, 2003; Chang, 2007). Światowy kryzys gospodarczy ujawnił również, że rynki nie były wystarczająco efektywne, a bez pomocy państwa dla poszczególnych przedsiębiorstw i sektorów gospodarka zarówno europejska, jak i amerykańska weszłyby w stan długotrwałej i głębokiej recesji (Stiglitz, Lin, Monga, 2013). Zaangażowanie wielu państw i międzynarodowych instytucji w pomoc dla branży finansowej rozpoczęło dyskusję, dlaczego w celu uniknięcia podobnych problemów nie ingerować szerzej w sferę realnej gospodarki (Warwick, 2013).

W powyższym kontekście głównymi czynnikami, które przyczyniły się do ożywienia dyskusji o konieczności realizowania bardziej aktywnej polityki przemysłowej w Polsce, były z jednej strony ogólnoświatowe zmiany w dyskursie na temat optymalnej 
polityki rozwojowej, z drugiej zaś - istotne znaczenie zaczęły odgrywać nowe wyzwania stojące przed polską polityką gospodarczą, w tym w szczególności rosnąca obawa przed wejściem w pułapkę średniego dochodu (Radło, Ciesielska, 2013; Ciesielska, Radło, 2014). Wzmożonej dyskusji o polityce przemysłowej w Polsce towarzyszy dodatkowo dążenie do „udomowienia” różnych branż polskiej gospodarki i wspierania rozwoju krajowych przedsiębiorstw (Török, Csuka, Kovács, Veres, 2013; Ślusarczyk, 2015).

Dodatkowym czynnikiem są powolne i niewystarczająco korzystne - pomimo utrzymującego się wzrostu gospodarczego - zmiany strukturalne w Polsce. Jak wskazują dane Głównego Urzędu Statystycznego (GUS, 2015), w strukturze produkcji sprzedanej polskiego przemysłu przetwórczego w latach 2010-2015 udział branży wysokiej i średnio wysokiej techniki spadł z 33,5 do 28\%. Co więcej, należy odnotować, że udział przychodów z tytułu sprzedaży produktów wysoko zaawansowanych technologicznie obniżył się z 6,8\% w 2010 roku do 4,8\% w 2015 roku. Oznacza to, że rola przemysłu wysokiej techniki w Polsce jest niewielka. Skutkuje to również niskim poziomem innowacyjności gospodarki - co potwierdzają wyniki badań prezentowanych w raportach European Innovation Scoreboard (European Commision, 2016). Takie cechy polskiej gospodarki - jak wskazują D.A. Ciesielska i M.J. Radło (2014) - czynią polską gospodarkę szczególnie podatną na wejście w pułapkę średniego dochodu. Pośrednio wskazują one, że polska polityka przemysłowa nie prowadzi do przesuwania się specjalizacji polskiej gospodarki w kierunku działalności bardziej innowacyjnych - pomimo że cele takie deklarowane były praktycznie we wszystkich dokumentach dotyczących polskiej polityki gospodarczej.

\section{POLITYKA PRZEMYSŁOWA W POLSCE W LATACH 2007-2014}

Do ważnych polskich rządowych programów strategicznych, które w latach 2007-2014 odnosiły się do polityki przemysłowej i określały jej cele oraz kierunki rozwoju, należą m.in. Strategia rozwoju kraju 2007-2015 (Ministerstwo Rozwoju Regionalnego, 2006), Koncepcja horyzontalnej polityki przemysłowej w Polsce (Ministerstwo Gospodarki, 2007) oraz Narodowe Strategiczne Ramy Odniesienia 2007-2013 wspierajace wzrost gospodarczy i zatrudnienie (Ministerstwo Rozwoju Regionalnego, 2007). Należy nadmienić, że działania zawarte w każdym z wymienionych powyżej dokumentów były ze sobą skoordynowane i zgodne z zaleceniami UE, tworząc spójny obraz strategii prowadzenia polityki przemysłowej.

W Strategii rozwoju kraju 2007-2015 (Ministerstwo Rozwoju Regionalnego, 2006) zawarto cele i priorytety polityki rozwoju w długiej perspektywie, które miały odpowiadać na wyzwania związane z procesem globalizacji i nowymi kierunkami wytyczonymi przez UE. Działania te zakładały wykorzystywanie cech polskiej gospodarki, stanowiących potencjalne źródło przewagi konkurencyjnej (np. relatywnie młode i coraz lepiej wykształcone kadry, wysoką przedsiębiorczość polskiego społeczeństwa, duży rynek wewnętrzny). W dokumencie tym zwrócono uwagę na konieczność podniesienia poziomu technologicznego gospodarki przez wzrost nakładów na badania i rozwój oraz innowacje, $w$ tym ekoinnowacje $w$ takich obszarach, jak: usługi, przemysł oraz rolnictwo. W celu zwiększenia konkurencyjności gospodarki założono przeprowadzenie głębokich zmian w strukturze produkcji przemysłowej poprzez nasycenie gospodarki wyrobami wysokiej techniki, bazującymi na nowoczesnych technologiach. Założono także wzmocnienie współpracy między przedsiębiorstwami i jednostkami naukowymi czy upowszechnienie stosowania prawa własności przemysłowej i praw pokrewnych. 
W Koncepcji horyzontalnej polityki przemysłowej w Polsce (Ministerstwo Gospodarki, 2007) zaprezentowano nowe podejście do polityki przemysłowej, mające na celu wsparcie długookresowego wzrostu i rozwoju polskiego przemysłu. Zgodnie z nim polityka ta miała polegać na stałym podnoszeniu jakości warunków ramowych prowadzenia działalności przemysłowej poprzez wspólne dla wszystkich branż działania ukierunkowane na podnoszenie konkurencyjności przedsiębiorstw przemysłowych. Dotychczasowe strategie branżowe miały zostać zastąpione analizami konkurencyjności oraz analizami rozwoju trendów technologicznych. W dokumencie nie wykluczono jednak całkowitej rezygnacji z prowadzenia polityki selektywnej, w tym w zakresie dwóch branż o szczególnym znaczeniu dla rozwoju kraju - energetycznej i obronnej. Do obszarów o kluczowym znaczeniu dla wzrostu konkurencyjności przedsiębiorstw przemysłowych wymagających interwencji państwa zaliczono: badania i rozwój oraz innowacyjność, technologie informacyjne i komunikacyjne, kapitał ludzki, ochronę środowiska - zrównoważony rozwój, rynki zbytu, ochronę własności przemysłowej, uproszczenie i poprawę systemu regulacji prawnych, dostęp do kapitału.

W dokumencie zaprezentowano również finansowe i niefinansowe instrumenty wsparcia dla powyższych obszarów, wynikające z różnych strategii i programów rządowych. Podstawowe źródło wsparcia finansowego stanowiły fundusze strukturalne dostępne w ramach centralnych i regionalnych programów operacyjnych w Narodowych Strategicznych Ramach Odniesienia na lata 2007-2013 wspierajacych wzrost gospodarczy i zatrudnienie (Ministerstwo Rozwoju Regionalnego, 2007). Natomiast do instrumentów niefinansowych zaliczono przede wszystkim propozycje zmian organizacyjno-prawnych mających na celu zlikwidowanie istniejących barier rozwojowych.

W Narodowych Strategicznych Ramach Odniesienia 2007-2013 wspierajacych wzrost gospodarczy i zatrudnienie (Ministerstwo Rozwoju Regionalnego, 2007) określono kierunki wsparcia ze środków finansowych w ramach Europejskiego Funduszu Rozwoju Regionalnego (EFRR), Europejskiego Funduszu Społecznego (EFS) oraz Funduszu Spójności. W dokumencie tym wskazano sześć celów, które miały wspierać wzrost gospodarczy i zatrudnienie w Polsce. Jeden z nich zakładał podniesienie konkurencyjności i innowacyjności przedsiębiorstw, ze szczególnym uwzględnieniem branż o wysokiej wartości dodanej, oraz rozwój sektora usług. Osiągnięciu tego celu miało służyć: wspieranie działalności wytwórczej przynoszącej wysoką wartość dodaną; rozwój sektora usług; poprawa otoczenia funkcjonowania przedsiębiorstw i ich dostępu do zewnętrznego finansowania; rozwój społeczeństwa informacyjnego; zwiększenie inwestycji w badania i rozwój oraz tworzenie rozwiązań innowacyjnych. Jego realizacja miała przebiegać przede wszystkim w ramach Programu Operacyjnego Innowacyjna Gospodarka (POIG), przy wsparciu regionalnych programów operacyjnych, Programu Operacyjnego Rozwój Polski Wschodniej (PORPW), Programu Operacyjnego Kapitał Ludzki (POKL) oraz Programu Operacyjnego Infrastruktura i Środowisko (POIŚ). Realizację tego celu oszacowano na 22\% środków przewidzianych do wydatkowania w ramach Narodowych Strategicznych Ram Odniesienia pomiędzy poszczególne cele horyzontalne.

Podsumowując, w latach 2007-2014 w Polsce była widoczna dominacja podejścia horyzontalnego do polityki przemysłowej, w którym państwo oddziałuje na przemysł poprzez poprawę warunków prowadzenia działalności gospodarczej. Wśród kluczowych deklarowanych celów takiej polityki było wspieranie działalności wytwórczej, przynoszącej wysoką wartość dodaną, rozwój sektora usług, podnoszenie 
innowacyjności gospodarki oraz rozwój społeczeństwa informacyjnego. Tym samym należałoby oczekiwać, że w badanym okresie główne kierunki wsparcia w postaci pomocy publicznej w Polsce powinny być wpisane w politykę przesuwania aktywności gospodarczej w kierunku branż bardziej innowacyjnych i cechujących się wyższą wartością dodaną. Warto więc na tym etapie przyjrzeć się głównym kierunkom udzielanej w badanym okresie pomocy publicznej.

\section{KIERUNKI POLITYKI PRZEMYSŁOWEJ W POLSCE W ŚWIETLE DANYCH O POMOCY PUBLICZNEJ ZA LATA 2007-2014}

Jak wynika z danych zaprezentowanych w tab. 1, w latach 2007-2014 ogólna wartość pomocy publicznej w Polsce była zmienna, przy czym od 2011 roku można odnotować jej wzrost. W 2014 roku wartość udzielonej pomocy publicznej wzrosła o ponad $14 \%$ w porównaniu z rokiem poprzednim. Jest to również największa wartość pomocy publicznej udzielonej w analizowanym okresie - 25 262,8 mln zł. Powodem takiej sytuacji było głównie rozpoczęcie udzielania przez ministra środowiska spółkom energetycznym pomocy $\mathrm{w}$ formie przydziału bezpłatnych uprawnień do emisji gazów cieplarnianych $(3,9$ mld zł) oraz znaczny wzrost wartości pomocy udzielonej dla transportu (1,9 mln zł - głównie na wsparcie transportu publicznego). Natomiast najniższa ogólna wartość udzielonej pomocy została odnotowana w 2007 roku. Jednakże kwota ta uwzględnia jedynie środki krajowe. W przypadku pomocy publicznej obejmującej również środki pochodzące z funduszy unijnych, finansujące lub współfinansujące pomoc najniższą wartość osiągnięto w 2008 roku. Udział ogólnej wartości pomocy w PKB w analizowanym okresie wahał się w granicach $0,6-1,7 \%$.

Tab. 1. Wartość pomocy publicznej w Polsce w latach 2007-2014 (w mln zł)

\begin{tabular}{|l|r|r|r|r|r|r|r|r|}
\hline \multicolumn{1}{|c|}{ Rok } & \multicolumn{1}{|c|}{2007} & \multicolumn{1}{c|}{2008} & \multicolumn{1}{c|}{2009} & \multicolumn{1}{c}{2010} & \multicolumn{1}{c|}{2011} & \multicolumn{1}{c|}{2012} & \multicolumn{1}{c|}{2013} & 2014 \\
\hline $\begin{array}{l}\text { Ogólna wartość } \\
\text { udzielonej pomocy }\end{array}$ & 6549,5 & 14383,1 & 19173,4 & 24087,3 & 21462,5 & 21795,6 & 22116,9 & 25262,8 \\
\hline $\begin{array}{l}\text { Wartość pomocy } \\
\text { Z wyłączeniem } \\
\text { transportu }\end{array}$ & 4847,2 & 11521,9 & 16087,2 & 21235,5 & 17955,1 & 18054,9 & 18154,6 & 19354,5 \\
\hline $\begin{array}{l}\text { Udział ogólnej wartości } \\
\text { pomocy w PKB (\%) }\end{array}$ & 0,60 & 1,13 & 1,43 & 1,70 & 1,40 & 1,37 & 1,35 & 1,46 \\
\hline $\begin{array}{l}\text { Udział wartości } \\
\text { pomocy z wyłączeniem } \\
\text { transportu w PKB (\%) }\end{array}$ & 0,41 & 0,91 & 1,2 & 1,5 & 1,17 & 1,13 & 1,11 & 1,12 \\
\hline
\end{tabular}

Uwagi: Kwoty za rok 2007 uwzględniają wyłącznie środki krajowe. Natomiast kwoty za lata 2008-2014 uwzględniają środki finansowe pochodzące z funduszy unijnych finansujące lub współfinansujące pomoc.

Źródło: opracowanie własne na podstawie raportów UOKiK dot. pomocy publicznej udzielonej przedsiębiorcom (UOKiK, 2008-2015)

W tab. 2 przedstawiono wartość pomocy publicznej w podziale na poszczególne rodzaje, tj. dotacje i ulgi, subsydia kapitałowo-inwestycyjne, tzw. miękkie kredytowanie oraz poręczenia i gwarancje. W całym analizowanym okresie najczęściej udzielana pomoc miała formę dotacji i ulg (grupa A), z czego najwięcej tego rodzaju pomocy udzielono w ramach dotacji, refundacji i rekompensat (grupa A1). Najwyższą wartość tego typu pomocy odnotowano w 2010 roku - 19 397,4 mln zł. W 2014 roku nastąpił 
natomiast wzrost wartości pomocy z grupy A o 1864,7 mln zł w porównaniu do roku poprzedniego. Wpływ na taką sytuację miał wzrost wartości pomocy z tytułu zwolnień i ulg podatkowych (grupa A2) o 860,7 mln zł. W przypadku pomocy w formach należących do grupy A1 odnotowano spadek ich udziału w ogólnej wartości pomocy o 7,4 p.p. Jednakże ich wartość bezwzględna pozostała na niezmienionym poziomie - ponad 15 mld zł. W 2014 roku znaczący spadek wartości tej formy pomocy (o 8017,8 mln zł) w porównaniu do 2013 roku (udzielanej w ramach regionalnych programów operacyjnych, PORPW, POIG czy z tytułu dobrowolnego rozwiązania umów długoterminowych sprzedaży mocy i energii elektrycznej) został zrekompensowany przez pomoc udzieloną przez ministra środowiska w formie przydziału bezpłatnych uprawnień do emisji gazów cieplarnianych (3901,5 mln zł).

Tab. 2. Wartość pomocy publicznej w Polsce w podziale na rodzaje w latach 2007-2014 (w mln zł)

\begin{tabular}{|l|r|r|r|r|r|r|r|r|}
\hline \multicolumn{1}{|c|}{ Rok } & \multicolumn{1}{c|}{2007} & \multicolumn{1}{c|}{2008} & \multicolumn{1}{c|}{2009} & \multicolumn{1}{c|}{2010} & \multicolumn{1}{c|}{2011} & \multicolumn{1}{c|}{2012} & \multicolumn{1}{c|}{2013} & 2014 \\
\hline Grupy A-E & 4847,2 & 11521,9 & 16087,2 & 21235,5 & 17955,1 & 18054,9 & 18154,6 & 19354,5 \\
\hline Grupa A & 4746,2 & 9380,9 & 13741,5 & 19397,4 & 17532,7 & 17188,5 & 17810,9 & 18277,9 \\
\hline Grupa A1 & 3644,1 & 7338,8 & 11323,2 & 16447,9 & 15358,1 & 15347,1 & 15667,8 & 15274,1 \\
\hline Grupa A2 & 1102,1 & 2042,1 & 2418,2 & 2949,4 & 2174,5 & 1841,4 & 2143,1 & 3003,8 \\
\hline Grupa B & 10,4 & 33,4 & 18,4 & 190,2 & 246,4 & 128,4 & 51,1 & 604,2 \\
\hline Grupa B1 & 10,4 & 33,4 & 18,4 & 190,2 & 246,4 & 128,4 & 51,1 & 130,7 \\
\hline Grupa B2 & 0,0 & 0,0 & 0,0 & 0,0 & 0,0 & 0,0 & 0,0 & 473,5 \\
\hline Grupa C & 66,8 & 348,1 & 191,9 & 338,5 & 159,3 & 736,1 & 289,9 & 421,7 \\
\hline Grupa C1 & 66,5 & 123,2 & 191,6 & 338,4 & 155,5 & 736,0 & 289,9 & 412,9 \\
\hline Grupa C2 & 0,3 & 224,9 & 0,3 & 0,2 & 3,8 & 0,1 & 0,0 & 8,8 \\
\hline Grupa D & 0,0 & 0,0 & 0,1 & 4,7 & 16,7 & 1,9 & 2,8 & 50,7 \\
\hline Grupa E & 23,8 & 1759,3 & 2135,3 & 1304,7 & 0,0 & 0,0 & 0,0 & 0,0 \\
\hline
\end{tabular}

Uwagi: Grupa A - dotacje i ulgi, grupa B - subsydia kapitałowo-inwestycyjne, grupa C - „miękkie kredytowanie”, grupa D - poręczenia i gwarancje, grupa E - inne. Kwoty za rok 2007 uwzględniają wyłącznie środki krajowe. Natomiast kwoty za lata 2008-2014 uwzględniają środki finansowe pochodzące z funduszy unijnych finansujące lub współfinansujące pomoc.

Źródło: opracowanie własne na podstawie raportów UOKiK dot. pomocy publicznej udzielonej przedsiębiorcom (UOKiK, 2008-2015)

W przypadku form pomocy z grupy B - subsydia kapitałowo-inwestycyjne - największą wartość odnotowano w 2011 roku - 246,4 mln zł. W latach 2007-2013 korzystano wyłącznie z pomocy grupy B1 - dokapitalizowanie. Natomiast w 2014 roku odnotowano znaczący udział - niewystępującej wcześniej w analizowanym okresie - pomocy z grupy B2 (konwersja wierzytelności na akcje lub udziały), której wartość wyniosła 473,5 mln zł i stanowiła 78,4\% łącznej pomocy grupy B. Była to przede wszystkim pomoc udzielona spółce Polskie Linie Lotnicze LOT SA przez ministra Skarbu Państwa.

W grupie C w analizowanym okresie największy udział miały pożyczki, kredyty preferencyjne (grupa C1). Ta forma pomocy najwyższą wartość osiągnęła w 2012 roku - 736 mln zł. W 2013 roku doszło jednak do znacznego obniżenia wartości tej pomocy - o 418,2 mln zł, a w 2014 roku na pomoc tę wydatkowano 412,9 mln zł. W 2014 roku odnotowano za to relatywnie wysoki wzrost wartości pomocy udzielonej w ramach grupy C2 (odroczenia terminu płatności, rozłożenia na raty należności) oraz D (poręczenia, gwarancje). 


\section{POMOC HORYZONTALNA I REGIONALNA}

W analizowanym okresie najwięcej na pomoc horyzontalną wydano w 2014 roku 8574,6 mln zł. W latach poprzednich wartość tego rodzaju wsparcia wahała się od 3175,7 mln zł do 6215,1 mln zł. Wzrost wartości pomocy horyzontalnej w 2014 roku spowodowany był przede wszystkim wzrostem wartości pomocy na ochronę środowiska i restrukturyzację. W latach 2009-2013 wartość pomocy regionalnej była wyższa niż pomocy horyzontalnej. Szczególnie widoczne różnice można zaobserwować w latach 2010 (10 716,3 mln zł) i 2013 (9457,1 mln zł). Powodem dominacji tego rodzaju wsparcia jest głównie wysoka wartość pomocy regionalnej udzielanej ze środków unijnych w ramach regionalnych programów operacyjnych oraz POIG. Ponadto wpływ na taką sytuację ma również możliwość korzystania ze zwolnień z podatku dochodowego przez przedsiębiorców, którzy prowadzą działalność gospodarczą w specjalnych strefach ekonomicznych (ryc. 1).

Jak wynika z danych na ryc. 2 , w ramach pomocy horyzontalnej, obszarami, które w analizowanym okresie otrzymały największe wsparcie, były odpowiednio: zatrudnienie (23 092,40 mln zł), ochrona środowiska (9063,2 mln zł), prace B + R (4809,8 mln zł) oraz szkolenia (3326,2 mln zł). Wsparcie w obszarze zatrudnienia w latach 2007-2014 utrzymywało się na zbliżonym poziomie, natomiast w zakresie ochrony środowiska znaczący wzrost pomocy zaobserwowano w 2014 roku. Powodem takiej sytuacji było udzielenie przez ministra środowiska pomocy spółkom energetycznym w formie przydziału bezpłatnych uprawnień do emisji gazów cieplarnianych. W przypadku prac badawczo-rozwojowych największe wsparcie zostało udzielone w latach 2012-2013. Największej pomocy z przeznaczeniem na szkolenia udzielono w 2009 oraz 2011 roku, przede wszystkim w ramach programu Refundacja wynagrodzeń młodocianych pracowników.

Dominujący udział w wartości pomocy regionalnej w analizowanym okresie miały wydatki na pomoc w celu wspierania nowych inwestycji - 51 155,6 mln zł. Na drugim

Ryc. 1. Wartość pomocy horyzontalnej i branżowej w Polsce w latach 2007-2014 (w mln zł)

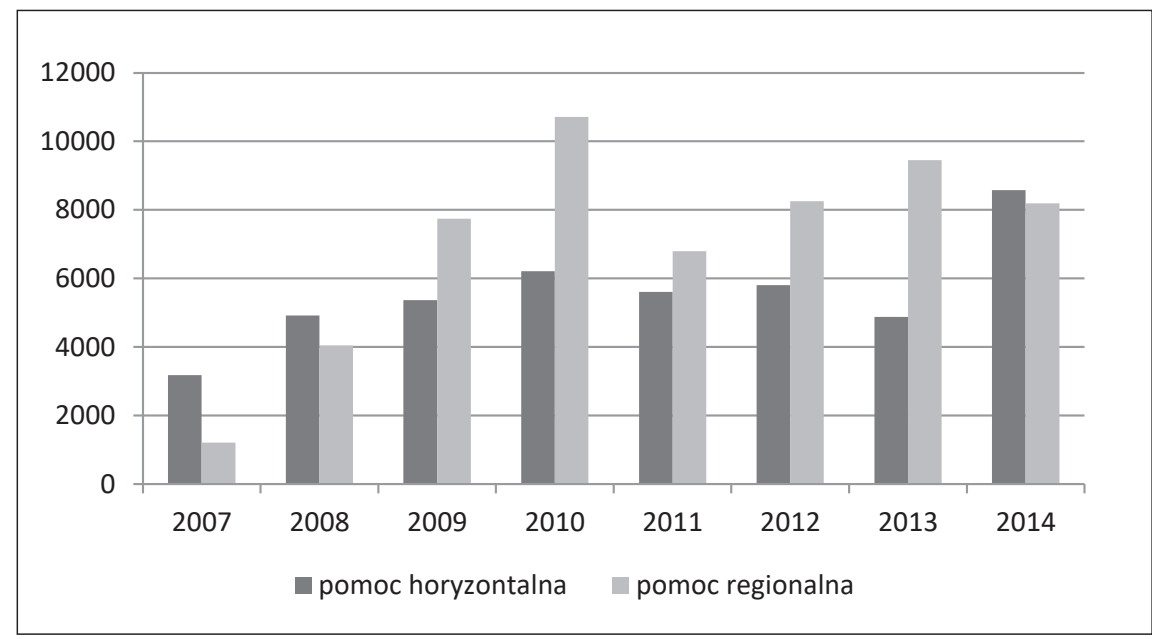

Źródło: opracowanie własne na podstawie raportów UOKiK dot. pomocy publicznej udzielonej przedsiębiorcom (UOKiK, 2008-2015) 
Ryc. 2. Wartość pomocy horyzontalnej w Polsce w podziale na wybrane obszary w latach 2007-2014 (w mln zł)

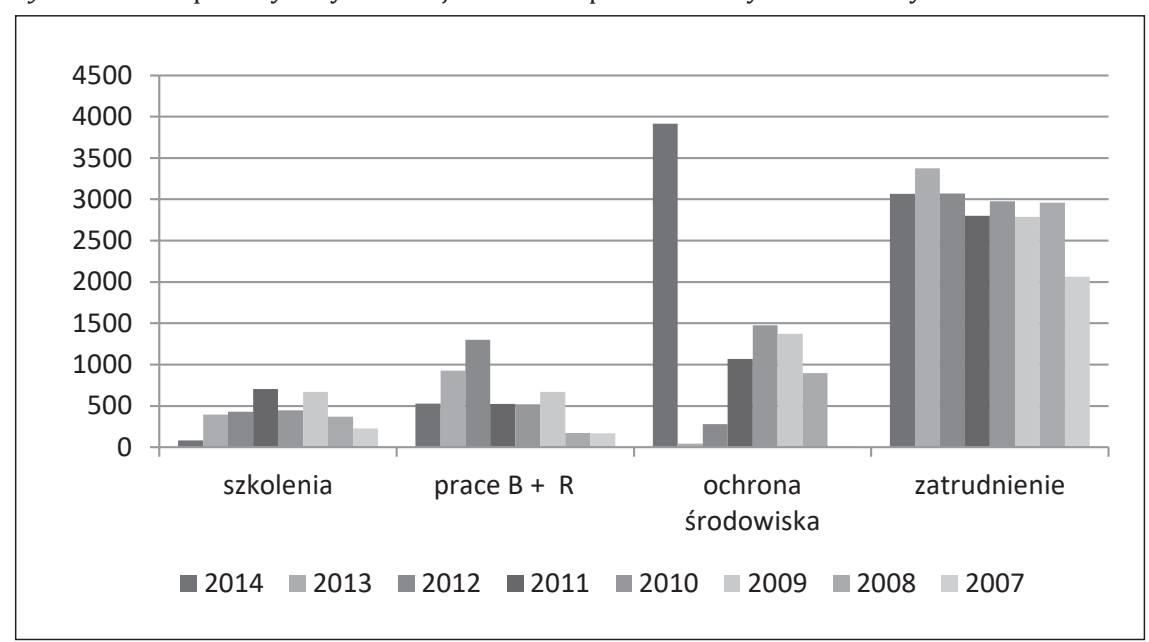

Źródło: opracowanie własne na podstawie raportów UOKiK dot. pomocy publicznej udzielonej przedsiębiorcom (UOwKiK, 2008-2015)

miejscu znalazła się pomoc w celu tworzenia nowych miejsc pracy - 2744,6 mln zł oraz wsparcie dużych projektów inwestycyjnych - 1886,4 mln zł (tab. 3). W 2010 i 2013 roku widoczne jest znaczące zwiększenie wydatków na pomoc w celu wspierania nowych inwestycji. Było to przede wszystkim efektem zwiększenia realizacji projektów inwestycyjnych finansowanych z regionalnych programów operacyjnych i POIG. W przypadku pomocy udzielonej w celu tworzenia nowych miejsc pracy najwięcej środków wydano w 2010 roku - 570,4 mln zł. Natomiast zdecydowanie mniejsze wydatki na realizację dużych projektów inwestycyjnych odnotowano w porównaniu do 2009 roku (558,4 mln zł) w kolejnych latach. Średnia roczna wartość tego wsparcia w okresie 2010-2014 wyniosła 257,54 mln zł.

Tab. 3. Wartość pomocy regionalnej w Polsce w podziale na wybrane obszary w latach 2007-2014 (w mln zł)

\begin{tabular}{|l|c|c|c|c|c|c|c|c|c|}
\hline \multicolumn{1}{|c|}{ Rok } & 2007 & 2008 & 2009 & 2010 & 2011 & 2012 & 2013 & 2014 & Ogółem \\
\hline $\begin{array}{l}\text { Pomoc } \\
\text { w celu } \\
\text { wspierania } \\
\text { nowych } \\
\text { inwestycji }\end{array}$ & 970,4 & 3784,1 & 6648,9 & 9714,0 & 5935,1 & 7311,8 & 8973,2 & 7818,1 & 51155,6 \\
\hline $\begin{array}{l}\text { Pomoc } \\
\text { w celu } \\
\text { tworzenia } \\
\text { nowych } \\
\text { miejsc pracy }\end{array}$ & 201,0 & 245,2 & 270,9 & 570,4 & 464,5 & 380,3 & 380,9 & 231,4 & 2744,6 \\
\hline $\begin{array}{l}\text { Duże } \\
\text { projekty } \\
\text { inwestycyjne }\end{array}$ & 33,2 & 7,1 & 558,4 & 275,5 & 387,5 & 380,3 & 103,0 & 141,4 & 1886,4 \\
\hline
\end{tabular}

Źródło: opracowanie własne na podstawie raportów UOKiK dot. pomocy publicznej udzielonej przedsiębiorcom (UOKiK, 2008-2015) 
Ryc. 3. Wartość pomocy branżowej ogółem w Polsce w latach 2007-2014 (w mln zł)

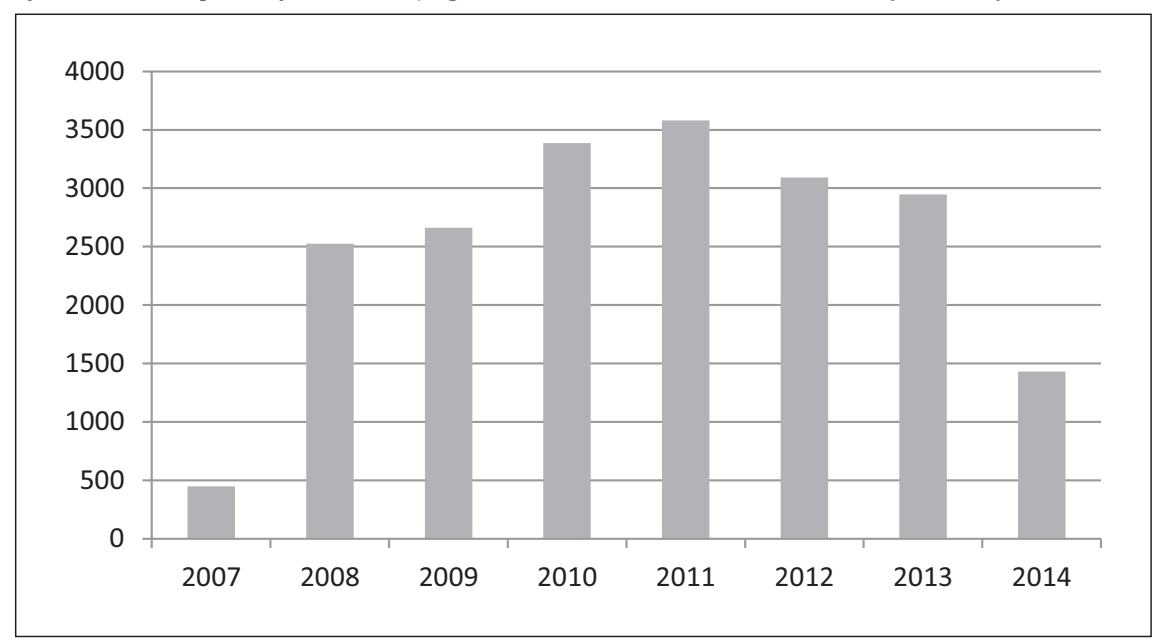

Źródło: opracowanie własne na podstawie raportów UOKiK dot. pomocy publicznej udzielonej przedsiębiorcom (UOKiK, 2008-2015)

\section{POMOC BRANŻOWA}

Łączna kwota wydana na pomoc branżową w latach 2007-2014 wyniosła 20 067,5 mln zł, z czego największe wsparcie zostało udzielone w 2010 (3387,6 mln zł) i 2011 roku (3578,9 mln zł). Wartość pomocy branżowej udzielonej w 2014 roku znacząco spadła w porównaniu z rokiem poprzednim (o $1516,7 \mathrm{mln} \mathrm{zł}$ ). W pozostałych latach, z wyjątkiem 2007 roku, wartość pomocy branżowej wahała się od 2524,5 mln zł do 3090,9 mln zł (ryc. 3).

Jak wynika $\mathrm{z}$ danych zaprezentowanych na ryc. 4, największe wsparcie $\mathrm{w}$ latach 2007-2014 otrzymały następujące branże: energetyczna, górnictwa węgla oraz gazu

Ryc. 4. Łączna wartość pomocy branżowej w Polsce w latach 2007-2014 (w mln zł)

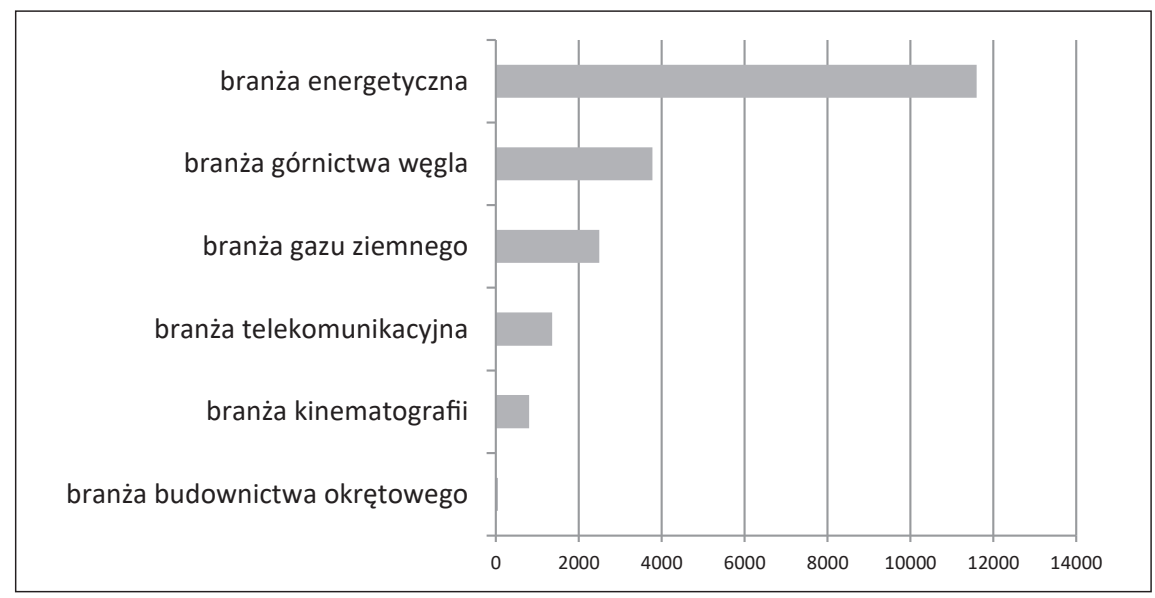

Źródło: opracowanie własne na podstawie raportów UOKiK dot. pomocy publicznej udzielonej przedsiębiorcom (UOKiK, 2008-2015) 
ziemnego. W przypadku pomocy dla branży energetycznej największy udział miała przede wszystkim pomoc z tytułu rekompensaty za rozwiązanie długoterminowych umów sprzedaży mocy i energii elektrycznej (KDT). Została ona udzielona w związku z procesem liberalizacji tego rynku. Branża górnictwa węgla otrzymała pomoc głównie w ramach programu pomocowego Pomoc państwa dla polskiego sektora węglowego w latach 2008-2015, natomiast branża gazu ziemnego otrzymała wsparcie przede wszystkim na rozwój projektów związanych z rozbudową infrastruktury na rynkach sieciowych gazu i energii.

\section{PoMOC UDZIELONA WEDŁUG BRANŻY DZIAŁALNOŚCI BENEFICJENTA}

W tab. 4 i na ryc. 5 zaprezentowano wartość pomocy udzielonej w latach 2011-2014 w podziale na branżę działalności beneficjenta - z pominięciem pomocy dla branży transportowej, ale z uwzględnieniem pomocy przedsiębiorcom na zasadach ogólnych (np. w ramach pomocy horyzontalnej czy regionalnej) lub zgodnie z wytycznymi wspólnotowymi dotyczącymi pomocy państwa w celu ratowania i restrukturyzacji zagrożonych przedsiębiorstw. Zestawienie zawiera 14 branż, na których wsparcie w poszczególnych latach wydano powyżej $500 \mathrm{mln}$ zł.

Tab. 4. Wartość pomocy w Polsce w podziale na branżę działalności beneficjenta w latach 2011-2014 (w mln zł)

\begin{tabular}{|c|c|c|}
\hline \multicolumn{2}{|r|}{ Dział PKD - branża działalności beneficjenta } & \multirow{2}{*}{$\begin{array}{r}\begin{array}{l}\text { Wartość } \\
\text { pomocy }\end{array} \\
12445,3\end{array}$} \\
\hline Dział 35 & $\begin{array}{l}\text { Wytwarzanie i zaopatrywanie w energię elektryczną, gaz, parę wodną, } \\
\text { gorącą wodę i powietrze do układów klimatyzacyjnych }\end{array}$ & \\
\hline Dział 80 & Działalność detektywistyczna i ochroniarska & 3834,3 \\
\hline Dział 25 & $\begin{array}{l}\text { Produkcja metalowych wyrobów gotowych, z wyłączeniem maszyn } \\
\text { i urządzeń }\end{array}$ & 2515,0 \\
\hline Dział 22 & Produkcja wyrobów z gumy i tworzyw sztucznych & 2444,6 \\
\hline Dział 38 & $\begin{array}{l}\text { Działalność związana ze zbieraniem, przetwarzaniem } \\
\text { i unieszkodliwianiem odpadów; odzysk surowców }\end{array}$ & 2387,5 \\
\hline Dział 29 & $\begin{array}{l}\text { Produkcja pojazdów samochodowych, przyczep i naczep, } \\
\text { z wyłączeniem motocykli }\end{array}$ & 2079,8 \\
\hline Dział 60 & Nadawanie programów ogólnodostępnych i abonamentowych & 2070,0 \\
\hline Dział 23 & $\begin{array}{l}\text { Produkcja wyrobów z pozostałych mineralnych surowców } \\
\text { niemetalicznych }\end{array}$ & 1795,1 \\
\hline Dział 72 & Badania naukowe i prace rozwojowe & 1154,3 \\
\hline Dział 20 & Produkcja chemikaliów i wyrobów chemicznych & 680,4 \\
\hline Dział 51 & Transport lotniczy & 600,5 \\
\hline Dział 19 & $\begin{array}{l}\text { Wytwarzanie i przetwarzanie koksu i produktów rafinacji ropy } \\
\text { naftowej }\end{array}$ & 571,4 \\
\hline Dział 28 & Produkcja maszyn i urządzeń, gdzie indziej niesklasyfikowana & 513,0 \\
\hline Dział 52 & Magazynowanie i działalność usługowa wspomagająca transport & 502,1 \\
\hline \multicolumn{2}{|c|}{ Pozostałe, w tym pomoc horyzontalna i sektorowa z wyłączeniem transportu } & 39925,8 \\
\hline \multicolumn{2}{|l|}{ Ogółem } & 73519,1 \\
\hline
\end{tabular}

Źródło: opracowanie własne na podstawie raportów UOKiK dot. pomocy publicznej udzielonej przedsiębiorcom UOKiK (2012-2015) 
Ryc. 5. Wartość pomocy w Polsce w podziale na branżę działalności beneficjenta w latach 2011-2014 (w mln zł)

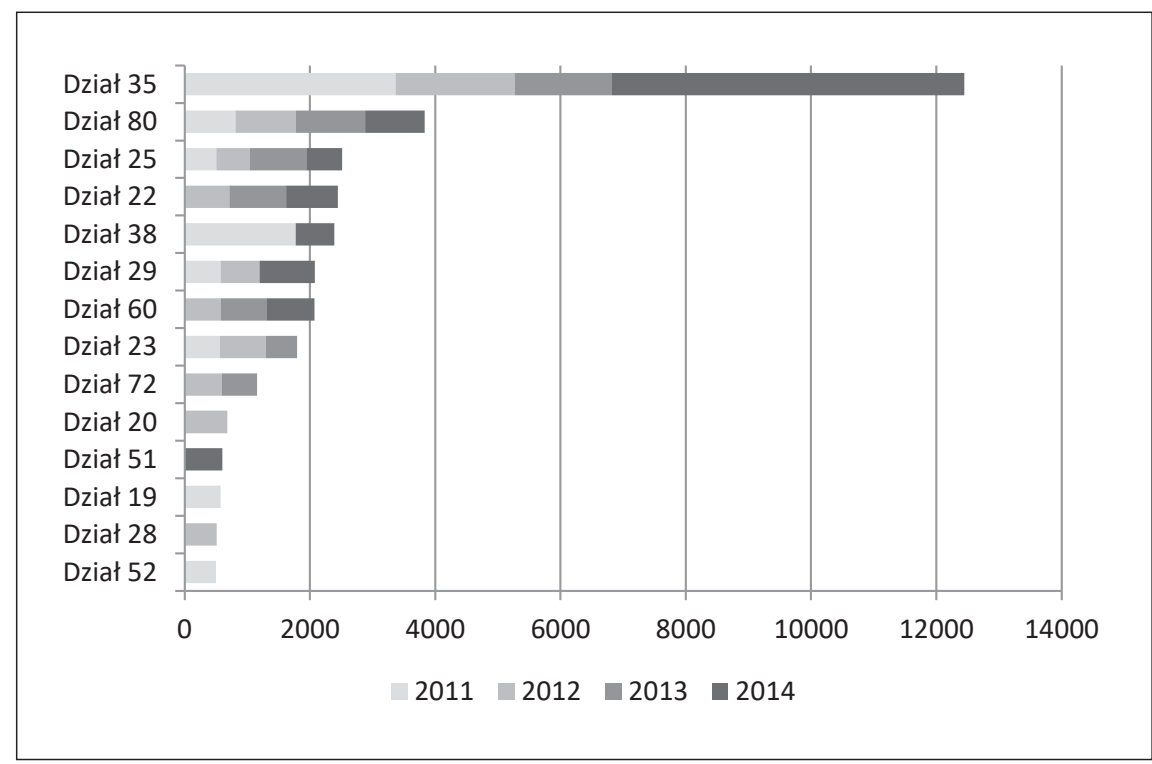

Źródło: opracowanie własne na podstawie raportów UOKiK dot. pomocy publicznej udzielonej przedsiębiorcom (UOKiK, 2012-2015)

Największą pomoc otrzymały podmioty zajmujące się wytwarzaniem i dystrybucją energii elektrycznej i paliw. W latach 2011-2014 wartość udzielonej tej branży pomocy wyniosła 12 445,3 mln zł i była finansowana przede wszystkim w ramach takich programów pomocowych, jak: derogacja z art. 10c dyrektywy 2003/87/EC o handlu emisjami - darmowe uprawnienia dla wytwórców energii elektrycznej; rekompensata za rozwiązanie długoterminowych umów sprzedaży mocy i energii elektrycznej; program pomocowy w zakresie regionalnej pomocy publicznej na niektóre inwestycje w ochronie środowiska; pomoc publiczna na inwestycje w zakresie budowy lub rozbudowy jednostek wytwarzających energię elektryczną lub ciepło z odnawialnych źródeł energii; wsparcie na modernizację systemów przesyłania lub dystrybucji ciepła.

Na drugim miejscu pod względem wielkości otrzymanej pomocy znaleźli się przedsiębiorcy prowadzący działalność detektywistyczną i ochroniarską. Łączna wartość wsparcia udzielonego w okresie 2011-2014 wyniosła 3834,3 mln zł, i pochodziła głównie z programu nr X306/2009 - Miesięczne dofinansowanie do wynagrodzeń pracowników niepełnosprawnych (3822 mln zł).

Na kolejnym miejscu znaleźli się producenci metalowych wyrobów gotowych, z wyłączeniem maszyn i urządzeń, którzy uzyskali wsparcie w wysokości 2515 mln zł. Pomoc ta została udzielona głównie w ramach: POIG na finansowanie badań, usług doradczych i szkoleń oraz na finansowanie nowych inwestycji o dużym znaczeniu dla gospodarki; programu regionalnej pomocy inwestycyjnej udzielanej w ramach regionalnych programów operacyjnych; programu Miesięczne dofinansowanie do wynagrodzeń pracowników niepełnosprawnych.

Kolejną grupą przedsiębiorców, która uzyskała znaczące wsparcie, są producenci wyrobów z gumy i tworzyw sztucznych. W latach 2012-2014 wartość pomocy w tej branży wyniosła 2444,6 mln zł. Została ona udzielona głównie w ramach POIG, 
kredytu technologicznego oraz zwolnienia z podatku dochodowego od osób prawnych ze względu na prowadzenie działalności na obszarze specjalnych stref ekonomicznych.

Znaczącą wartość pomocy uzyskały również podmioty zajmujące się działalnością związaną ze zbieraniem, przetwarzaniem i unieszkodliwianiem odpadów. W latach 2011 i 2014 otrzymały one łączne wsparcie w wysokości 2387,5 mln zł, przede wszystkim w ramach rekompensaty z tytułu realizacji zadań publicznych oraz POIG. Znaczące wsparcie otrzymali również producenci pojazdów samochodowych. Najwięcej - 886,5 mln zł otrzymali w 2014 roku, przede wszystkim w ramach programu pomocy dla przedsiębiorców prowadzących działalność w specjalnych strefach ekonomicznych.

Nadawcy programów radiowo-telewizyjnych otrzymali natomiast w latach 20122014 wsparcie w wysokości 2070 mln zł, które stanowiło głównie rekompensatę z tytułu realizacji zadań publicznych. Kolejną grupą przedsiębiorców, która otrzymała znaczącą pomoc, byli producenci wyrobów z mineralnych surowców niemetalicznych. Wartość udzielonego wsparcia w latach 2011-2013 wyniosła 1795,1 mln zł. Pomoc pochodziła głównie z POIG oraz z programu pomocy dla przedsiębiorców prowadzących działalność w specjalnych strefach ekonomicznych.

Istotną pomoc otrzymali również przedsiębiorcy zajmujący się działalnością badawczo-rozwojową. W latach 2012-2013 uzyskali oni wsparcie w wysokości 1154,3 mln zł, udzielone w ramach POIG z przeznaczeniem na realizację nowych inwestycji o dużym znaczeniu dla gospodarki oraz na badania, usługi doradcze i szkolenia, a także w ramach programu Warunki i tryb udzielania pomocy publicznej i pomocy de minimis realizowanego za pośrednictwem Narodowego Centrum Badań i Rozwoju.

Pozostałe branże uzyskały w analizowanym okresie pomoc nieprzekraczającą wartości 1 mld zł. W przypadku branży chemikaliów i wyrobów chemicznych znaczącej pomocy udzielono w 2012 roku w ramach POIG z przeznaczeniem na sfinansowanie nowych inwestycji o dużym znaczeniu dla gospodarki (356,2 mln zł). Natomiast przedsiębiorstwem, które otrzymało w 2014 roku pomoc w wysokości 600,5 mln zł z branży transportu lotniczego, były Polskie Linie Lotnicze LOT SA (numer sprawy pomocy indywidualnej SA.36874(2013/C). Na kolejnym miejscu znaleźli się wytwórcy produktów rafinacji naftowej, którym w 2011 roku udzielono pomocy zwłaszcza w ramach programu pomocowego Pomoc operacyjna w zakresie biopaliw (481,3 mln zł). Ostatnią branżą, która w 2011 roku uzyskała pomoc o wartości powyżej $500 \mathrm{mln}$ zł, była branża magazynowania i działalności wspomagającej transport. Największe wsparcie w tym obszarze zostało udzielone w ramach pomocy indywidualnej Budowa terminalu regazyfikacyjnego skroplonego gazu ziemnego w Świnoujściu (440,9 mln zł).

W tab. 5 przedstawiono zestawienie powyższych danych z klasyfikacją przetwórstwa przemysłowego i usług według intensywności B + R. Z przeprowadzonej analizy wynika, że istotna część pomocy nie została skierowana do żadnego z przedsiębiorstw zajmujących się wytwarzaniem produktów wysokiej techniki, tj. podmiotów zajmujących się produkcją podstawowych substancji farmaceutycznych oraz leków i pozostałych wyrobów farmaceutycznych; produkcją komputerów, wyrobów elektronicznych i optycznych; produkcją statków powietrznych, statków kosmicznych i podobnych maszyn. Można natomiast wyróżnić przedsiębiorców świadczących usługi wysokiej techniki, którym została udzielona znacząca wartość wsparcia. W latach 2012-2013 pomoc została skierowana na realizację badań naukowych i prac rozwojowych (1154,3 mln zł), a w latach 2012-2014 znaczące środki pomocowe otrzymali nadawcy programów ogólnodostępnych i abonamentowych (2070 mln zł). 
W przypadku przemysłu średnio wysokiej techniki głównymi beneficjentami byli producenci pojazdów samochodowych, chemikaliów i wyrobów chemicznych oraz maszyn i urządzeń (gdzie indziej niesklasyfikowanych). Należy jednak zauważyć, że pomoc o znaczącej wartości w ostatnich dwóch branżach została udzielona przedsiębiorcom jedynie w 2012 roku i stanowiła jedną z najniższych wartości w porównaniu do pozostałych obszarów.

Tab. 5. Zestawienia wartości udzielonego wsparcia z klasyfikacją przetwórstwa przemysłowego i usług według intensywności B + R

\begin{tabular}{|c|c|c|c|}
\hline \multicolumn{3}{|r|}{ Przemysł } & \multirow[b]{2}{*}{ Kwota } \\
\hline $\begin{array}{c}\text { Typ branży } \\
\text { według } \\
\text { poziomu } \\
\text { techniki }\end{array}$ & PKD & $\begin{array}{l}\text { Branża działalności } \\
\text { beneficjenta }\end{array}$ & \\
\hline \multirow{4}{*}{$\begin{array}{l}\text { Średnio } \\
\text { wysoka } \\
\text { technika }\end{array}$} & 29 & $\begin{array}{l}\text { Produkcja pojazdów samochodowych, przyczep i naczep, } \\
\text { z wyłączeniem motocykli }\end{array}$ & 2079,8 \\
\hline & 20 & Produkcja chemikaliów i wyrobów chemicznych & 680,4 \\
\hline & 28 & Produkcja maszyn i urządzeń, gdzie indziej niesklasyfikowana & 513,0 \\
\hline & \multicolumn{2}{|r|}{ Ogółem } & 3273,2 \\
\hline \multirow{5}{*}{$\begin{array}{l}\text { Średnio niska } \\
\text { technika }\end{array}$} & 25 & $\begin{array}{l}\text { Produkcja metalowych wyrobów gotowych, z wyłączeniem } \\
\text { maszyn i urządzeń }\end{array}$ & 2515,0 \\
\hline & 22 & Produkcja wyrobów z gumy i tworzyw sztucznych & 2444,6 \\
\hline & 23 & $\begin{array}{l}\text { Produkcja wyrobów z pozostałych mineralnych surowców } \\
\text { niemetalicznych }\end{array}$ & 1795,1 \\
\hline & 19 & Wytwarzanie i przetwarzanie koksu i produktów rafinacji & 571,4 \\
\hline & & Ogółem & 7326,1 \\
\hline \multicolumn{4}{|c|}{ Usługi } \\
\hline \multirow{3}{*}{$\begin{array}{l}\text { Usługi wysokiej } \\
\text { techniki }\end{array}$} & 60 & Nadawanie programów ogólnodostępnych i abonamentowych & 2070,0 \\
\hline & 72 & Badania naukowe i prace rozwojowe & 1154,3 \\
\hline & \multicolumn{2}{|c|}{ Ogółem } & 3224,3 \\
\hline \multirow{4}{*}{ Usługi rynkowe } & 80 & Działalność detektywistyczna i ochroniarska & 3834,3 \\
\hline & 51 & Transport lotniczy & 600,5 \\
\hline & 52 & $\begin{array}{l}\text { Magazynowanie i działalność usługowa wspomagająca } \\
\text { transport }\end{array}$ & 502,1 \\
\hline & & Ogółem & 4936,9 \\
\hline
\end{tabular}

Źródło: opracowanie własne na podstawie raportów UOKiK dot. pomocy publicznej udzielonej przedsiębiorcom (UOKiK, 2012-2015) oraz GUS (2015)

Głównymi odbiorcami pomocy w przemyśle średnio niskiej techniki były podmioty zajmujące się produkcją metalowych wyrobów gotowych, z wyłączeniem maszyn i urządzeń, wyrobów z gumy i tworzyw sztucznych, wyrobów z pozostałych mineralnych surowców niemetalicznych oraz produktów rafinacji ropy naftowej.

Natomiast podmiotom świadczącym usługi rynkowe, takie jak: usługi detektywistyczne i ochroniarskie, transportu lotniczego oraz usługi magazynowania i wspomagające transport, udzielono pomocy w wysokości 4936,9 mln zł. Należy przy tym 
zauważyć, że to podmioty zajmujące się działalnością detektywistyczną i ochroniarską stanowiły ok. 78\% pomocy udzielonej podmiotom świadczącym usługi rynkowe, które otrzymały znaczącą wartość pomocy.

\section{PODSUMOWANIE I WNIOSKI}

Podsumowując, można zauważyć, że podejście do polityki przemysłowej zmieniało się wraz z upływem czasu. Wybór narzędzi i działań w zakresie tej polityki może być zupełnie odmienny, a kluczowa różnica sprowadza się do tego, czy polityka przemysłowa powinna mieć charakter sektorowy, horyzontalny, czy powinna łączyć w sobie elementy każdej z nich. Ostatni kryzys gospodarczy, spadek konkurencyjności europejskich gospodarek, a także narastająca konkurencja ze strony krajów wschodzących doprowadziły do zmiany nastawienia do prowadzenia polityki przemysłowej. Zaobserwowano odejście od skrajnie liberalnego podejścia i włączenia do niego elementów polityki selektywnej. Obecnie polityka przemysłowa kładzie nacisk na reindustrializację.

W Polsce w latach 2007-2014 przygotowano kilka dokumentów odnoszących się do kierunków prowadzenia polityki przemysłowej, m.in. Strategię rozwoju kraju 20072015, Koncepcję horyzontalnej polityki przemysłowej w Polsce oraz Narodowe Strategiczne Ramy Odniesienia 2007-2013 wspierajace wzrost gospodarczy i zatrudnienie z 2007 roku. W dokumentach tych zwrócono uwagę na konieczność podniesienia poziomu technologicznego gospodarki przez wzrost wydatków na badania i rozwój oraz innowacje, w takich obszarach, jak przemysł, usługi oraz rolnictwo. Jednym z celów było zwiększenie konkurencyjności polskiej gospodarki, czemu miało przysłużyć się wspieranie produkcji przemysłu wysokiej techniki, bazującego na nowoczesnych technologiach. Polityka taka miała doprowadzić do stałego podnoszenia jakości warunków ramowych prowadzenia działalności przemysłowej poprzez wspólne dla wszystkich branż działania ukierunkowane na podnoszenie konkurencyjności przedsiębiorstw. Nie wykluczono jednak całkowitej rezygnacji z prowadzenia polityki selektywnej.

Z analizy danych dotyczących udzielonej pomocy publicznej wynika, że od 2011 roku wartość udzielanego wsparcia stopniowo wzrasta. W 2014 roku nastąpił wzrost pomocy publicznej w porównaniu z poprzednim rokiem o ponad 14\%. Zgodnie z założeniami polityki przemysłowej wartość pomocy horyzontalnej oraz regionalnej jest zdecydowanie wyższa niż wartość pomocy branżowej, która była skierowana do branży górnictwa węgla, telekomunikacyjnej, gazu ziemnego, budownictwa okrętowego, energetycznej oraz kinematografii.

Jednakże w ramach pomocy publicznej udzielonej w latach 2011-2014 największe wsparcie nie trafiło do podmiotów produkujących dobra wysokiej czy chociażby średnio wysokiej techniki, a do przedsiębiorstw przemysłowych średnio niskiej techniki oraz podmiotów świadczących usługi rynkowe, tj. usługi detektywistyczne i ochroniarskie, transportu lotniczego oraz magazynowania i wspomagania transportu.

Wyniki przeprowadzonego badania wskazują, że realizacja polityki przemysłowej nie odpowiadała w pełni celom, jakimi miało być m.in. podniesie poziomu technologicznego polskiej gospodarki, dopasowanie polskiego przemysłu do zmian strukturalnych w światowej gospodarce i podniesienie jego konkurencyjności. W najbliższej przyszłości niezbędne wydaje się więc zrewidowanie dotychczasowego sposobu prowadzenia polityki przemysłowej i jej instrumentów, tak aby efektywniej wspierała ona rozwój 
polskich przedsiębiorstw działających w przemyśle wysokiej i średnio wysokiej techniki. To one są bowiem odpowiedzialne za tworzenie innowacyjnych technologii, które we współczesnej gospodarce są kluczowym i niezbędnym zasobem do budowania trwałej przewagi konkurencyjnej.

\section{Literatura \\ References}

Ambroziak, A.A. (2015). Europeanization of Industrial Policy: Towards Re-Industralization? W: P. Stanek, K. Wach (red.). Europeanization Processes from the Mesoeconomic Perspective: Industries and Policies. Kraków: Uniwersytet Ekonomiczny w Krakowie, 61-94.

Becker, G. (1985). The best industrial policy is none at all. Business Week, 26.

Chang, H.-J. (2007). Bad Samaritans. The Myth of free trade and the secret history of capitalism. London: Bloomsbury Press, 23-45.

Ciesielska, D.A., Radło, M.J. (2013). Determinanty wejścia w pułapkę średniego dochodu: perspektywa Polski. Kwartalnik Nauk o Przedsiębiorstwie, 2(31), 5-13.

European Commission (2016). European Innovation Scoreboard. Executive summary, 2-3.

Gawlikowska-Hueckel, K. (2014). Polityka przemysłowa i spójności wobec planów reindustrializacji Unii Europejskiej. Wnioski dla Polski. Gospodarka Narodowa, 5(273), 53-80.

Gorynia, M. (1996). Koncepcja liberalno-instytucjonalnej polityki przemysłowej. Gospodarka Narodowa, 1-2.

GUS (2015). Nauka i technika w 2014 roku. Warszawa.

Harrison, A., Rodriguez-Clare, A. (2010). Trade Foreign Investment and Industrial Policy. Handbook of Development Economics, 5, 40-98.

Ministerstwo Gospodarki (2007). Koncepcja horyzontalnej polityki przemysłowej w Polsce. Warszawa.

Ministerstwo Rozwoju Regionalnego (2006). Strategia rozwoju kraju 2007-2015. Warszawa.

Ministerstwo Rozwoju Regionalnego (2007). Narodowe Strategiczne Ramy Odniesienia 20072013 wspierające wzrost gospodarczy i zatrudnienie. Warszawa.

Radło, M.J. (2016). Offshoring, Outsourcing and Production Fragmentation. Linking Macroeconomic and Micro-Business Perspectives. Basingstoke and New York: Palgrave Macmillan.

Radło, M.J., Ciesielska, D.A. (2013). Polska w pułapce średniego dochodu? Warszawa: Wydawnictwo Difin.

Rynarzewski, T. (2003). Cło wychowawcze i cło optymalne w teorii i praktyce polityki handlu międzynarodowego. Ruch Prawniczy, Ekonomiczny i Socjologiczny, 1, 91-106.

Spałek, P. (2015). Protekcjonizm wychowawczy w warunkach wolnego rynku. Ekonomika i Organizacja Przedsiębiorstwa, 7, 92-97.

Stiglitz, J.E., Lin, J.Y., Monga, C. (2013). The Rejuvenation of Industrial Policy. World Bank Policy Research. Working Paper, 6628, 2-18.

Ślusarczyk, B., (2009). Horizontal Industrial Policy in Poland. Annales Universitatis Apulensis Series Oeconomica, 11(2), 910-917.

Ślusarczyk, B. (2015). The Requirement of New Industrial Policy to Support Polish Economy. Procedia Economics and Finance, 27, 93-101.

Török, A., Csuka, G., Kovács, B., Veres, A. (2013). The "resurrection" of industrial policy in the European Union and its impact on industrial policy in the New Member Countries. Work Package 306 MS69 Research paper on a new industrial policy for catch-up economies. Working Paper, 26. Pozyskano z http://www.foreurope.eu/

Ulbrych, M. (2016). Europeanisation of Industrial Policy: Towards a Re-Industralisation of Europe. W: P. Stanek, K. Wach (red.). Macro-, Meso- and Microeconomic Dimensions of Europeanisation. Warszawa: Wydawnictwo Naukowe PWN, 121-140.

UOKiK (2008). Raport o pomocy publicznej w Polsce udzielonej przedsiębiorcom w 2007 roku. Pozyskano z https://uokik.gov.pl/raporty_i_analizy2.php

UOKiK (2009). Raport o pomocy publicznej w Polsce udzielonej przedsiębiorcom w 2008 roku. Pozyskano z https://uokik.gov.pl/raporty_i_analizy2.php. 
UOKiK (2010). Raport o pomocy publicznej w Polsce udzielonej przedsiębiorcom w 2009 roku. Pozyskano z https://uokik.gov.pl/raporty_i_analizy2.php

UOKiK (2011). Raport o pomocy publicznej w Polsce udzielonej przedsiębiorcom w 2010 roku. Pozyskano z https://uokik.gov.pl/raporty_i_analizy2.php

UOKiK (2012). Raport o pomocy publicznej w Polsce udzielonej przedsiębiorcom w 2011 roku. Pozyskano z https://uokik.gov.pl/raporty_i_analizy2.php

UOKiK (2013). Raport o pomocy publicznej w Polsce udzielonej przedsiębiorcom w 2012 roku. Pozyskano z https://uokik.gov.pl/raporty_i_analizy2.php

UOKiK (2014). Raport o pomocy publicznej w Polsce udzielonej przedsiębiorcom w 2013 roku. Pozyskano z https://uokik.gov.pl/raporty_i_analizy2.php

UOKiK (2015). Raport o pomocy publicznej w Polsce udzielonej przedsiębiorcom w 2014 roku. Pozyskano z https://uokik.gov.pl/raporty_i_analizy2.php

Wade, R.H. (2015). The Role of Industrial Policy in Developing Countries. W: A. Calcagno, S. Dullien, A. Márquez-Velázquez, N. Maystre, J. Priewe (red.). Rethinking Development Strategies After the Financial Crisis, Volume I: Making the Case for Policy Space. New York and Geneva: United Nations.

Warwick, K. (2013). Beyond Industrial Policy: Emerging Issues and New Trends. OECD Science, Technology and Industry Policy Papers, 2, OECD Publishing. Pozyskano z http://dx.doi. org/10.1787/5k4869clw0xp-en

Mariusz Jan Radło, prof. nadzw. dr hab., kierownik Zakładu Globalnych Współzależności Gospodarczych. Jest doktorem habilitowanym nauk ekonomicznych (SGH, 2015), uzyskał doktorat nauk ekonomicznych (SGH, 2003), ukończył studia magisterskie w zakresie ekonomii (Uniwersytet Marii Curie-Skłodowskiej, 1998) i politologii (UMCS, 1999), a także podyplomowe studia w zakresie integracji europejskiej w Krajowej Szkole Administracji Publicznej i Ecole Nationale d'Administration (1999). Od 2004 roku jest pracownikiem naukowym i dydaktycznym Szkoły Głównej Handlowej w Warszawie. Jest również partnerem zarządzającym w spółce analityczno-doradczej SENDICO. W latach 2004-2007 był wicedyrektorem ds. naukowych Polskiego Forum Strategii Lizbońskiej w Instytucie Badań nad Gospodarką Rynkową.

Mariusz Jan Radło, an associate professor of economics and head of Global Economic Interdependence Unit in World Economy Research Institute at the SGH. He holds D.Sc. in Economics (2015, Warsaw School of Economics - SGH) and a Ph.D. in Economics (SGH, 2003). He gained a Master's degree in Economics (1998) and Political Science (1999) at the Maria Curie Skłodowska University in Lublin. He also holds a postgraduate degree in European Integration from the National School of Public Administration (Poland) and the Ecole Nationale d'Administration (France). Since 2004, he has worked as a research fellow and lecturer at the Warsaw School of Economics. He is also managing partner at SEENDICO - Warsaw based analytical and strategic consulting company. Between 2004-2007, he was the vice president for research of the Polish Lisbon Strategy Forum at the Gdańsk Institute for Market Economics.

Paulina Spałek, mgr, absolwentka Szkoły Głównej Handlowej w Warszawie oraz Uniwersytetu Warszawskiego, a także stypendystka na Uniwersytecie Johanna Gutenberga w Moguncji. Obecnie realizuje studia doktoranckie w Kolegium Gospodarki Światowej w Szkole Głównej Handlowej w Warszawie. Jej zainteresowania badawcze i naukowe koncentrują się na tematyce międzynarodowej konkurencyjności gospodarczej, polityce przemysłowej oraz ekonomicznych aspektach integracji europejskiej.

Paulina Spałek, M.Sc., a graduate of the Warsaw School of Economics and the Warsaw University. She received a scholarship at the Johannes Gutenberg University of Mainz. Currently, she is a Ph.D. student at the Warsaw School of Economics. Her research interests include international economic competitiveness, industrial policy and economic aspects of European integration.

\section{Adres/address:}

Szkoła Główna Handlowa w Warszawie

Kolegium Gospodarki Światowej

Instytut Gospodarki Światowej

Zakład Globalnych Współzależności Gospodarczych

ul. Rakowiecka 24, 02-521 Warszawa, Polska

e-mail: mjradlo@sgh.waw.pl (Mariusz Jan Radło)

e-mail: ps55696@doktorant.sgh.waw.pl (Paulina Spałek) 